\title{
Specifics of Accounting Recognition and Reflection of Government Assistance Funds for Agro-industrial Complex Organizations
}

\author{
Irina Sergeeva ${ }^{1}$ \\ ${ }^{1}$ Moscow University of Finance and Law MFUA, Moscow, Russian Federation \\ Correspondence: Irina Sergeeva, Moscow University of Finance and Law MFUA, Vvedenskogo Street, 1a, \\ Moscow, 117342, Russian Federation. E-mail: Sergeeva.Ir@mfua.ru
}

Received: September 24, 2014

Accepted: October 10, 2014 Online Published: February 25, 2015

doi:10.5539/ass.v11n6p144

URL: http://dx.doi.org/10.5539/ass.v11n6p144

\begin{abstract}
Despite the economy denationalization, a great number of non-budgetary organizations (state and municipal unitary enterprises as well as economic partnerships and companies) are still financed from the budget to a varying degree. Budgetary financing is a non-repayable provision of state budgetary funds to enterprises, institutions, organizations to cover their expenses in full or partially. Besides, there are transactions with characteristics of targeted financing in the economic practice and between commercial organizations. Almost in all countries, government and assistance is rendered to agricultural enterprises to ensure their effective work. As a rule, funds allocated for the sector support are earmarked and strictly controlled by government authorities in terms of compliance with their destination.
\end{abstract}

Keywords: targeted financing, government assistance, subsidy, subvention, public budget loan, grant

\section{Introduction}

Targeted financing is a gratuitous receipt of funds, which may be used only according to the purpose of the subject that has allocated these funds. That is, to consider receipts special-purpose, a condition should be fulfilled, according to which the person transferring them should not claim the result of the funds use or their return (Sergeeva, 2014).

To spend funds on supporting one or another sector most effectively, the government develops targeted programs. They contain precise information about the works, for which the funds will be allocated, terms and amount of the funds allocation. This prevents the allocated funds from being spent on other purposes. The programs are mainly financed from the budget. However, sometimes other sources are involved, too. For instance, funds may be allocated by wealthy companies. For this, they receive tax concessions. Recipients of funds may, in their turn, expand the production capacities and upgrade the equipment, restore the premises or carry out research (Bourtsev, 1999).

\section{Method}

Government assistance is rendered to agricultural goods producers both at the expense of the federal budget and funds of the constituents of the Russian Federation. According to the Accounting Regulations PBU 13/2000 "Government Assistance Accounting", the government assistance is considered to be an increase in economic benefits of a particular organization as a result of the assets income (Provision on accounting, 2006). The government assistance is rendered to commercial organizations in the form of:

- Subventions;

- Subsidies;

- Public budget loans, including provision in the form of resources other than monetary funds (land plots, natural resources and another property).

The Budget Code of the Russian Federation of 31.07.1998 No. 145-FZ defines the notions of subvention and subsidy (Budget Code of the Russian Federation, 1998).

The subvention is budgetary funds provided to the budget of another level of the budget system of the Russian Federation or legal entity free of charge and irrevocably to undertake certain targeted expenditures (Tronin, 2011). 
For instance, subventions allocated from the federal budget for financing activities on state procurement interventions regarding bread grain. Or subventions granted from the budgets of constituents of the Russian Federation, for instance, in Kaluga Region, for construction (acquisition) of accommodation for agricultural workers (Gusarova, 2011).

The subsidy is budgetary funds provided to the budget of another level of the budget system of the Russian Federation, individual or legal entity on the terms of targeted expenses shared financing. They include compensation of part of expenses on purchasing mineral fertilizers and plant protection chemicals, grants for manufacturing plant and livestock products, crops insurance (Gusev, 2005).

The public budget loan is a form of budgetary expenses financing, which presupposes funds provision to legal entities on returnable and repayable bases.

\section{Results}

The intended use of budgetary funds is regulated by the Budget Code of the Russian Federation, normative documents of the constituents of the Russian Federation.

The government assistance for agriculture financing is rendered both on a returnable basis (a leasing fund for acquiring new machinery and equipment, purchasing breeding animals, concessional lending of agricultural seasonal expenses) and on a non-returnable basis (investments in targeted activities-amelioration, acquisition of mineral fertilizers and plant protection chemicals, subsidies for production of flax and hemp, support for livestock breeding, etc.). Non-returnable targeted financing and receipts are source of an increase in the equity capital of the organization (Pancakes, 2010).

For instance, when registering the property formed on the basis of the targeted financing of capital construction or working capital replenishment, the cost of this property is charged to an increase in the additional capital of the organization.

The procedure for the provision of subsidies from the federal budget for the government support of individual agricultural branches is approved annually by the Government of the Russian Federation in accordance with the Federal Law "On the Federal Budget" for the next financial year. The procedure for the provision of subsidies and other types of government assistance for the support of agriculture and other agro-industrial complex branches from the local budgets and budgets of the constituents of the Russian Federation is annually approved by the corresponding structures of the local and regional authorities (Matyushina, 2005).

\section{Discussion}

The basic subsidies from the federal budget (the list may be corrected annually) are granted for the following types of expenses (Kundius, 2012):

a) support for the reindeer breeding:

- on keeping animals on reindeer breeding farms at the established rate per a head of reindeer on the basis of the number of head accounted by the state statistical authorities at the beginning of the present year;

b) support for the livestock breeding:

- on keeping highly productive breeding stock of farm animals on breed livestock farms included in the list approved by the Ministry of Agriculture of the Russian Federation upon agreement with the executive bodies of the constituents of the Russian Federation at the established rate per a conditional head;

- on keeping breeding stock of fur-bearing animals included in the list approved by the Ministry of Agriculture of the Russian Federation upon agreement with the executive bodies of the constituents of the Russian Federation at the established rate per a conditional head;

- on keeping breeding stud bulls at enterprises on stock breeding and artificial animal insemination at the established rate per a conditional head;

c) support for the domestic sheep farming:

- on keeping breeding stock of sheep and goats on sheep and goat breeding farms at the established rate per a head of an ewe and goat on the basis of the number of head accounted by the state statistical authorities at the beginning of the present year;

d) support for the elite seed production:

- on acquiring elite seeds of agricultural plants for multiplication and strain changing, strain renovation (Order of the Ministry of Agriculture of the Russian Federation, 2004) 
There are two ways of recognizing non-repayable assets in accounting in the international accounting practice: charging them to the capital increase or income increase.

International Accounting Standard 20 "Accounting for Government Grants and Disclosure of Government Assistance" distinguishes two types of government subsidies as forms of resource transfer to an organization in exchange for fulfilling specific conditions connected with the company's operating activities in the past or future:

- subsidies related to the assets, the main conditions for providing the organization with which are purchase, construction or long-term assets acquisition as well as provision of subsidies in the form of a non-monetary asset;

- subsidies unrelated to the assets.

Up to 1999 inclusively, the first method was used in the Russian accounting: non-repayable funds, including targeted financing of capital investments and current activities were reflected on account 87 "Additional Capital" (besides, the property acquired at the expense of the targeted financing was not depreciated). Since January 1, 2000, in connection with the adoption of the Accounting Regulations "Organization's Incomes" (PBU 9/99) and "Organization's Expenses" (PBU 10/99) and introduction of a new Chart of Accounts, such receipts have resulted in the appearance of other incomes and expenses in the corresponding periods (Lushina \& Slepova, 2006).

Accounting of special-purpose receipts as well as government assistance on a non-returnable basis is carried out on nominal account 86 "Targeted Financing". Receipt of funds is reflected on the credit of account 86; expenses, on the debit. Analytical accounting on account 86 is carried out according to the destination of the earmarked funds and in terms of the receipt sources (Stefanova \& Tkachenko, 2008).

The primary documents for the accounting of government support and targeted financing funds are notices about assignment of limits to the budget financing less than one or another article, letters of advice coming from the treasury bodies. Documents, which confirm the fact of a financing funds receipt, are remittance order, documents on the receipt of commodities and materials received against the subsidies (Tumusov, 2009).

PBU 13/2000 "Government Assistance Accounting" presupposes two options of accepting the government assistance for accounting. In the first case, receipt of monetary and non-monetary funds is accounted as the budgetary funds actually get to the debit of the corresponding accounts $(51,52,10,11$, etc.) and directly to the credit of account 86. In the second case, government assistance accounting should be carried out with the use of transit account 76 "Settlements with Different Debtors and Creditors" (Kolyadinsky, 2008; Krokhina, 2007).

If the government assistance funds have been allocated for financing non-current assets (federal budget funds for capital investments), the amount of the allocated government assistance is charged to the incomes of the accounting period in proportion to the accrued depreciation over the whole period of operating the acquired (produced) permanent assets (Shokhin, 2014).

If the current expenses, which include subsidies for the production of flax and hemp, elite seed production maintenance, animal breeding development (breeding business, sheep breeding, etc.), have been financed at the expense of the budget funds, the writing-off takes place during registration of the corresponding end products (Sergeeva \& Gubernatorova, 2013).

Thus, subsidies are regarded not as additional sources of funds, but as a mechanism for lowering the prime cost of the produced products. Surely, this method was very convenient under the conditions of the centralized economy. During the drawing up of consolidated reports, when indicators of the superior and inferior enterprises, subject granting the subsidy and subsidy recipient were united in one document, such a method ensured accountant officers' labor minimization. It was possible to receive general data on the agriculture of a region, okrug, country without special expenses, since there was no need for eliminating the double count (Babaev \& Petrov, 2012). It is interesting that the international accounting does not refute such an option, either. International standards on financial accounting allow reflecting separate subsidies in the above described way (Karagod, 2012).

Accounting of government subsidies (government grants) is also regulated by IAS 41 "Agriculture". According to IAS 41, government subsidies (grants) considered as biological assets that are stated at fair value, and may be limited and not limited by any conditions. Conditions limited subsidy is reflected as income only after total fulfillment of Accounting for Government Grants are also regulated by IAS 41 "Agriculture". According to IAS 41 are government subsidies to biological assets, at fair value, and may be limited or restricted by any conditions. Limited conditions the grant relates to income only after all the conditions set forth in its issuance and unconditional government grant is recognized as income after it is clearly recognized to be received, regardless of the actual date de moneys.

Thus, IAS 20 is the basic standard defining form of government assistance, and requires its disclosure in the following aspects: 
- The direction of accounting policies selected to reflect the state subsidies, including ways of presenting the financial statements;

- The origin and extent of government grants recognized in the financial statements and notes on other forms of government support as a result of which the company received a direct benefit;

- Recognition of the outstanding conditions for granting state support.

These features of accounting earnings targets relate only to those businesses that receive earmarked funds as grants. At the same time, each of the target budget programs has its performers. For them, the funds are the proceeds of the shipped goods, works or services. Consequently, in the account of such organizations, in addition to the target revenue is also reflected the sale of goods (works, services):

- The cost of targeted interventions;

- The costs of the administrative staff;

- The cost of acquisition of fixed assets, inventory and other assets.

In case of excess expenditure over the amount of revenue, the difference is shown as a surplus at the end of the reporting period in parentheses clarification on this matter is given in the explanatory note.

In the accounts of the organization (in the explanatory note) must be disclosed, as a minimum, the following information in respect of the trust fund:

- The nature and the magnitude of the budget, recognized in the accounting records in the reporting year;

- The purpose and value of the cost of credit;

- The nature of other forms of government assistance from which the organization directly receives the economic benefits;

- Not made at the balance sheet date the terms of the budget and related contingent liabilities and contingent assets.

As part of a specialized part of the annual financial statements for the formation of organizations AIC information provided forms of government assistance and use a separate form number 10-APK "Statement of purpose funds." Form number 10-APK detailed manner discloses the subsidies received by agricultural producers. Items are grouped in this form of financing is made in accordance with the distribution of the budget allocated to the Ministry of Agriculture of Russia from the federal budget under the "Agriculture and Fisheries". Subsidies should be shown only to the extent that either have already received on account of the organization, or, of course, will be available (there are a notice or other documents confirming the intention of the budget to transfer funds to the organization). If a grant is in doubt, then you should not take it to the bang-up business accounting until the amount of the grant to be paid is not exactly confirmed by the financial authorities.

In the form of a number of 10-APK reveal all kinds of subsidies, fiscal year, including VAT. Each amount of the grant may be reflected in the form of a specific line number 10-APK only once. Help you fill out papers report to accurately determine the name of subsidy. Territorial authorities may identify some types of subsidies to reflect them in separate lines. In a separate line should reflect the amount of subsidies received to recover damages from natural disasters.

On a separate line for reference is the sum of the reference calculations, by the company and submitted to the territorial bodies for funding. These amounts may not reflect the actual funding and must be justified by production performance of the organization itself. On the basis of these data should be made of the size actually received subsidies and necessary for its volumes Agriculture Organization.

The main directions of improving the organization of accounting determined by reference to the transition to a market economy. It is important to bring the national accounting practices in comparability with the practice of Western countries, which need to improve accounting, introduce progressive forms and methods of accounting.

Purpose funds for agricultural organizations are state aid, which must be used for its intended purpose and efficiently. The current legislation in the field of accounting is no clear definition of target financing and detailed methodology of its account and not provided completeness of accounting budget as earmarked funding; no analytical account of the budget according to the forms of state aid and the directions of its use, there is no accounting registers of state aid.

Budgetary funds provided in the prescribed manner to finance the costs incurred by the organization in the previous report, periods of recognized as the onset of the debt on such funds and an increase in the financial 
results of the organization's other income. Obtained for this purpose state aid because it does not affect the accounting records in the above account of 86 "Targeted Financing" shall be disclosed in the notes to the balance sheet and profit and loss account. Such an approach to the integration of budget funds can contribute to inappropriate use, as well as their assignment. In addition, the amount of these funds will not be shown or reflected in the notes to the balance sheet. Consequently, information on state aid in the annual financial statements will be incomplete.

In this regard, do not ensure complete accounting of budgetary funds in the form of state aid as targeted financing, namely:

- Budgetary funds allocated to cover the costs of past periods of the ne;

- Cost of credit;

- There is practically no analytical accounting budget for state aid forms and directions of use.

In the regions, there is no real independent system of effective financial control over the efficiency of the formation and the lawful orders of budgetary funds. Agricultural companies are almost impossible to track the timeliness and reliability of accounting for the budget. The enterprise does not have any supervisory bodies. Agricultural producers who receive budgetary funds are not liable for the proper use and their return, due to lack of proper supervision by the creditors. The result is a distraction budgetary allocation or diversion.

More efficient use of budgetary funds in agro industrial complex will contribute to the creation of monitoring bodies in organizations and develop provisions for the Audit Commission or the Internal Audit Department.

In accordance with IAS 20 "Accounting for Government Grants and Disclosure of Government Assistance" reflection of subsidies is made by one of three ways:

1) at the same time the entire amount of the subsidy to the credit of the Profit and Loss-kah;

2) at the same time as the entire amount of the unallocated reserve (fund);

3) the distribution of the grant as income on the useful life of the asset the following options:

- reducing the purchase price of the asset in the amount of subsidies,

- carrying amount of grant as deferred income that year refers to the financial results.

Of the three ways to reflect government subsidies has pre-property last option considered. However, arising under this option the obligation to state subsidies cannot be considered as accounting obligation, as it is seen in the account as deferred credits, or payable to the budget, extra-budgetary funds, employees of the organization and so on.

\section{Conclusion}

Summarizing the above mentioned ideas, we come to the conclusion that the targeted financing funds are funds meant for the financing of earmarked activities by an enterprise. They include funds received from the budget, sector and inter-sectoral special-purpose funds, other organizations, individuals for the earmarked activities conduction. The earmarked funds may be intended for payment of capital or current expenses of the enterprise. Capital expenses are those on purchase, construction or another non-current asset acquisition. The rest of the enterprise's expenses are current ones.

\section{References}

Babaev, Y. A., \& Petrov, A. M. (2012). International Financial Reporting Standards: A Textbook. Moscow: College textbooks: INFRA-M.

Bourtsev, V. (1999). Management Control System as. Management in Russia and abroad, 5.

Budget Code of the Russian Federation of 31.07.1998 No. 145-FZ. (1998).

Gusarova, L. V. (2011). Targeted funding and dedicated revenues: Methodology. Accounting in the budget and non-profit organizations, 20.

Gusev, E. E. (2005). Development of management accounting in the current economic conditions. Modern accounting, 2.

Karagod, V. S. (2012). International Financial Reporting Standards: A textbook for bachelors. Moscow: Publishing Yurait.

Kolyadinsky, A. A. (2008). Taxation and accounting of trust funds. Russian Tax Courier, 23, 10-14. 
Krokhina, Y. (2007). Some aspects of accounting and tax subsidies provided from the budgets of the subjects of the Russian Federation to businesses. Financial newspaper, 33, 16-19.

Kundius, V. A. (2012). Formation of clusters in the village-the basis of innovative development of agricultural production. Economy agricultural and processing enterprises, 2, 56-60.

Lushina, S. I., \& Slepova, V. A. (2006). State and Municipal Finance: A Textbook. M.: Economist.

Matyushina, E. V. (2005). Target financing. Glavbukh, branch application, Accounting education, 1, 13-19.

Order of the Ministry of Agriculture of the Russian Federation. (2004). On approval of the guidelines on accounting in the agricultural organizations of government grants and other types of public assistance.

Pancakes, A. A. (2010). On the terminology of budgeting. Managerial Accounting, 1(99).

Provision on accounting "Accounting for government assistance" PBU 13/2000. (2006). Approved by Order of the Ministry of Finance of the Russian Federation of 18.09.2006, No. 115n.

Sergeeva, I. A. (2014). Accounting state aid and raw materials supplied. Accounting in agriculture, 9, 74-77.

Sergeeva, I. A., \& Gubernatorova, N. N. (2013). Features of economic development of Russia until 2030. International and regional issues of national economic development in modern conditions: Collection of research papers based on the XII International Scientific-Practical Conference/Edited by PhD in Physics and Math, associate D.K. Nikiforov. Kaluga: Publisher "Eidos".

Shokhin, S. O. (2014). Legal problems of financing the federal target programs. Legal World, 1, 51-55.

Stefanova, S. N., \& Tkachenko, I. Y. (2008). Accounting for agricultural and processing enterprises. M.: Phoenix.

Tronin, S. A. (2011). Principles of investment planning at the enterprise. Journal of Modern Economy: Problems and Solutions, 2(14), 101.

Tumusov, F. S. (2009). Investment potential of the region: The theory, problems, and practice. M.: Economics.

\section{Copyrights}

Copyright for this article is retained by the author(s), with first publication rights granted to the journal.

This is an open-access article distributed under the terms and conditions of the Creative Commons Attribution license (http://creativecommons.org/licenses/by/3.0/). 